\title{
Today’s Choices for Selecting a School: What is the Emerging Story?
}

\author{
Margaret M. Ferrara \\ University of Nevada Reno (UNR), Reno, NV, USA
}

\begin{abstract}
Today, "equity" and "a quality education" are at the forefront of education conversations at the family dinner table, the local diner, and the editorial page of the newspaper. Why? Local and national efforts are increasing to meet students' needs academically and developmentally. Families strive to address their children's needs educationally through a relevant support system couched in a well-matched learning environment. This paper provides an overview of possible ways that students and their families can select an education setting that creates this broad match, more commonly identified as school choice. These choices include but are not limited to private charter schools, public charter schools, public schools, and home-schools as well as single-gender schools. This study will summarize fundamental differences among various learning environments and conclude with a set of questions to analyze what indeed is the best environmental match for each child's learning needs.
\end{abstract}

Keywords: school choice, private charter schools, public charter schools, public schools, home-schools, single-gender schools

\section{Introduction}

"Equity" and "a quality education" are at the forefront of conversations about school choice. Local and national efforts are increasing to meet the needs of individual students wherever they are and provide relevant support to overcome obstacles that may be preventing them from a fair chance at an education in a public school. Twenty-five percent of families are considering moving their children to another school based on better opportunities to hone strong skills for future employment (Great Schools, 2017).

Some critics of private schools believe that a private school experience removes the child from authentic real-life experiences. Some proponents of private schools believe that these schools provide more of a focused opportunity to learn a specific set of skills (e.g., career and technical education) or talents (e.g., theatre). This paper attempts to capture a broad understanding of school choices today: charter schools—public and private, as well as public schools and home-schools (National Alliance for Public Charter Schools, 2017). It also presents a synthesis of the multiple variables that come into play when parents are deciding the school that is the best fit for their children.

To find the school that is the best fit, looking at reports from broad and narrow perspectives is helpful. One-way is to look at each type of school's characteristics overall and to discern attributes, namely, educational environments and curricula that may assist local school districts in closing the achievement gap. A closer investigation of issues related to equity (e.g., race, socio-economic level, gender, and violence) provides a more 
comprehensive contrast of the different choices in schools (Institute of Education Sciences [IES]/National Center for Education Statistics [NCES], 2017).

\section{Some Overall Distinctions Between Public Schools vs. Private Schools}

It is important to address the distinctions between public and private schools. The first distinction is that public schools do not charge tuition. Education ratings help create a rationale for purchasing a home in a high-star rated school as compared to a low-star rated school. Some families also use a rationale that splits the difference — electing to purchase a less expensive home to afford the tuition for a private school.

The second distinction is that public schools are funded by taxes-federal, state, and local. They are accountable for rules and regulations locally, state, and nationally. However, private schools generate their funding sources and many times. This funding is provided by tuition that ranges in cost from $\$ 10,841$ at a minimum to $\$ 25,000$ in exclusive private schools (National Student Clearinghouse, 2015).

What is more, public schools accept all students and provide accommodations for special needs and gifted students. But private schools can add a clause in their admission standards that they do not provide services for students with special needs or those who need accommodations. There are ranges of other differences—class size, teacher preparation, and curriculum selection. Private schools have more choice in how they organize their classrooms and daily schedule, select their teaching staff, and evaluate their curriculum outcome scores (IES/NCES, 2017; Niche, 2017; Public School Review, 2016).

\section{Comparison of Public Charter Schools vs. Charter Schools}

\section{The Similarities Between Public Charter Schools and Charter Schools}

In a more specific comparison, looking at public charter schools compared to charter schools, there are many similarities. Public charter schools are open to all children, do not charge tuition, and do not have a special entrance requirement (National Alliance for Public Charter Schools, 2017; Social Solutions, 2017). These schools are funded publically and typically follow governance by a group or organization under a legislation contact, namely, a charter with the state, school district, or other entity.

\section{The Difference Between Public Charter Schools and Charter Schools}

The difference is that a public charter school has fewer state regulations and more potential for flexibility. It is important that the public charter school still needs to meet the accountability standards outlined in its charter and these are reviewed periodically to ensure that the charter is aligned with the practices at the public charter school. If the guidelines are not followed or the standards are not met, the charter can be revoked (Abdul-Alim, 2016).

\section{The Difference Between Private School and Charter Schools}

Charter schools have a charter approved typically by the state. Unlike a private school, a charter school depends upon money from the government to operate. In contrast to a private school, a charter school has less freedom to operate and make decisions. Both private and charter schools can receive accreditation and typically charter schools are more likely accredited than private schools (Social Solutions, 2017).

\section{A Focus Look at Single-Gender Public Charter Schools}

There are many examples of public charter schools, which operate only for boy's schools, such as the 
Urban Prep Academies in Chicago and the Eagle Schools in New York, and operate only for girl's schools, such as the Young Women's Leadership Network of Schools in New York. Presently, middle school public charters make up the majority (47\%) of schools in the United States (U.S.) followed by high school (34\%), and lastly, the kindergarten to Grade 6 (K-6) made up 28\%.

The single-gender public schools that were open in 2003 have decreased. Most of the single-gender charter public schools are located in large urban settings, for example, Capital Prep in the Bronx supported by Rapper Puff Daddy, Eagle Academy of Staten Island, Urban Prep Academies, and the Cesar Chavez Public Charter Schools for Public Policy in Washington, D.C.. The principal locations of single-gender public schools are within the eastern U.S., while the rest of single-gender public charter schools reside mostly in large urban areas surrounding Chicago, Cleveland, Miami, Dallas, and Houston. There "appear to be” zero all boys' public schools west of Texas. All but two schools (located in the southern states) serve a student population with more than 84\% African American and Hispanic, and 16 schools are 98\% diverse. Many students in these schools are on $100 \%$ free/reduced lunch (Ferrara \& Holback, 2015).

Studies based on boys' and girls' performance in single-gender schools as compared to mixed gender schools shows that both groups showed modest advantages in their performance in mathematic but not for science (Pahlke, Hyde, \& Allison, 2014).

\section{Home-Schooling}

\section{Overview}

A commonly held belief is that home-schooling means that the parent (or a designee) teaches the child in the home, providing whatever instruction is needed to educate the child. There are many alternatives, including co-ops, enrichment classes, drop-off classes, tutoring programs, dual enrollment, charter schools, satellite schools, courses offered by the public school system in the home, on-line courses, home-school umbrella organizations, home-school programs connected to private academies, and correspondence courses. Many of these options take place elsewhere with the teaching done by someone other than the parents. The parents still make the decisions and direct the instruction, but they do not necessarily do the teaching.

The bulk of a student's learning may happen outside the home or at home in an atmosphere where learning can take place. Those who have embraced home-schooling report many benefits, which include the ability to adjust each child's learning needs and the flexibility in setting up a learning schedule. Home-schooling allows the teacher to bring in the child's interest and talents and support learning needs. There is no set time limit in learning to master a concept or skill. A child can explore a topic more in-depth or take more time to learn about a difficult concept. A comprehensive study from 1998 to 2008 of 250 home-school families in Pennsylvania noted that there were significant changes in home-school programs. By the end of the study, programs were using a religious and non-religious curricula as well as school district textbooks and technology applications. Also, there were more collaborative sharing of resources and levels of expertise with school consultants and a more organized network of other home-schooling families (Hanna, 2012).

Research on investigating issues related to equity and diversity related to home-schooling have brought in evidence that African American home-schoolers were able to gain a more comprehensive understanding of American history beyond the typical ethnocentric curriculum found in many public schools (Mazama \& Lundy, 2013). There has also been a positive shift in the attitude those admission officers' attitudes toward and perceptions of the home-schooled graduates. More than $78 \%$ of surveyed admission officers indicated that they 
expect home-school graduates to performs well or to bet their first year of college as compared to traditional high school graduates (Gloechner \& Jones, 2013). Perhaps, the most consistent negative press for home-schooling is that studies on home-school outcomes-job preparation skills, civic engagement, and academic success—are not substantiated with research studies that have high response rates (Lubienski, Puckett, Brewer, \& Jameson, 2013).

\section{Complexities of Data Collection for Students who are Home-Schooled}

Researchers, especially those in the past 15 years, had found that the family who elects to home-school are unique. The typical home-school family is not like describing the typical public school family-the range of demographics, philosophies, and practices make such a generalization practically impossible (Kunzman, 2009, p. 313). One of the reasons for this issue is that each state in the Union has a unique way in terms of collecting data and regulating home-schooling guidelines. Those who elect home-schooling have most commonly cited one of three reasons for their choice to educate their child or children through home-schooling: a poor learning environment in school (31\%), religious reasons (30\%), and a lack of fit with the capabilities of special education to gifted students (31\%) (Isenberg, 2007). Then, establishing an accurate count of how many students are being home-schooled is not able to be reported with high accuracy. Some students who are receiving home-school are not reported to the government and researchers. This is a practice referred to as underground home-schooling (Isenberg, 2007). This adds complexity to the awareness of levels of students in a home-school setting although it has been estimated that from one to two million children are learning at home (IES/NCES, 2017; Ray, 2011).

\section{Shifts in Population Among Public Schools, Public Charter Schools, Charter Schools, Private Schools, and Home-Schooling}

Over the past two decades, the range of options that parents have for the education of their children has expanded (Mead \& Green, 2012). Private schools have been a traditional alternative to public school education, but there are now more options for parents to choose public charter schools or charter schools, and more parents are also home-schooling their children. Between Fall in 1999 and Fall in 2013, enrollment in private schools decreased from 6.0 million to 5.4 million, which means a decline of 0.6 million or $10 \%$. During the same period, the percentage of elementary and secondary students enrolled in private schools declined from $11.4 \%$ to $9.7 \%$.

In contrast, enrollment in public charter schools increased between Fall in 1999 and Fall in 2013, rising from 0.3 million to 2.5 million, which means an increase of 2.2 million students. During this period, the percentage of public elementary and secondary school children who were in charter schools increased from $0.7 \%$ to $5.1 \%$.

Also, there has been an increase in the percentage of 5-17 years old who are home-schooled. About 1.8 million children were home-schooled in 2012 compared to 0.9 million in 1999. The increase is also mirrored in the number of students, who are in school, especially schools with a population larger than 300 students. Charter public schools increased by 1.8 million students (from 0.9 million to 2.7 million). Over the past two decades, the range of options that parents have for the education of their children has expanded. Private schools have been a traditional alternative to public school education. Now, there are more options for parents to choose public charter schools and more parents are also home-schooling their children. 


\section{Who is Attending Schools on Ethnic and Socio-Economic Levels}

An interesting change in public charter schools that have emerged from 2004 to 2014 is that public charter schools are the response to the question, "Who is attending a public charter school?" (IES/NCES, 2017) The population of students in public charter schools who are Hispanic increased from $22 \%$ to $31 \%$, as did the percentage of students who were Asian/Pacific islander (from 3\% to 4\%). White students who attended public charter schools decreased from $42 \%$ to $34 \%$. There was also a reduction for African-American students (from $31 \%$ to 27\%) and American Indian/Alaska Native (from 2\% to 1\%). The percentage of students attending high-poverty schools (students who qualify for free or reduced lunch) was higher for public charter schools (35\%) as contrasted with traditional public school students (24\%) (IES/NCES, 2017).

\section{Family Choice in Selecting a School}

Charter schools are the typical form of choice available to parents within the public education sector. However, some opportunity for parental choice also can be found in traditional public schools. In 2012, 37\% parents of all Grades 1-12 students indicated that public school choice was available. Also, in 2012, 13\% students in traditional public schools were in a school chosen by their parents rather than an assigned school. There were differences in the characteristics of students attending their local assigned public schools in 2012 compared to those in public schools chosen by their parents. For example, White students made up a higher percentage of those in assigned schools (53\%) than of those in chosen schools (40\%).

In contrast, African-American students made up a higher percentage of those in chosen schools (22\%) than of those in assigned schools (14\%). For Hispanic students, chosen schools are $27 \%$ and assigned schools are $23 \%$. For students in cities, chosen schools are $46 \%$ and assigned schools are $25 \%$. In contrast, for students in rural areas assigned schools are $26 \%$ and chosen schools are 14\% (IES/NCES, 2017). Compared with students in assigned public schools, a higher percentage of students in chosen public schools had parents who were very satisfied with some elements of their children's education in 2012. Among students in Grades 3-12, the percentage of students whose parents were very happy with their school was higher for students in schools of choice (56\%) than for students in assigned (public) schools (52\%).

Similarly, the percentage of students whose parents were very satisfied with their school's academic standards was higher for students in chosen schools (59\%) than for students in assigned schools (53\%). Also, higher percentages of students in choice schools had parents who were very satisfied with school order and discipline (58\% vs. 52\%) as well as with staff interaction with parents (49\% vs. $45 \%)$. However, there was no measurable difference between the percentages of students in choice and assigned public schools whose parents were highly satisfied with the teachers in their school (52\% each) (IES/NCES, 2017).

\section{Males and Females in Today's Schools}

There continues to be a difference in the graduate rate of males in the kindergarten to Grade 12 (K-12) schools as compared to females. Although the national high school dropout rate for boys is half of what it was in 1985, it continues to trend downward. Boys still have a higher high school dropout rate (7.2\% in 2013) than females (6.3\% in 2013) (IES/NCES, 2017). One of the reasons is the lower level of aspiration for males to continue an education beyond high school. In the 1980s, although seniors of both genders had similar expectations about graduating from college and attending graduate school, girls already had higher aspirations 
(close to $2 \%$ points) than boys did. By the 2000s, the expectations index for both college and graduate school was $8 \%$ points higher for girls than boys. Gender differences in aspirations for college and graduate school are respectively $8 \%$ points and $11 \%$ points greater in favor of girls. Six percent of boys vs. $3 \%$ of girls have declared no postsecondary aspirations. This trend begins in among Grade 8 , already $4 \%$ girls are more than boys report being enrolled in a college preparatory program although a significant proportion of students (43\% of both boys and girls) have not made clear choices yet.

The number of males graduating from college is roughly $10 \%$ less than females (IES/NCES, 2017). This trend is even more evident when variables, such as race and socio-economic level are brought into the discussion. Males of African American and Hispanic backgrounds have a combined dropout rate of 20.8\%, which has decreased by roughly 53\% since 1985 due to national attention on racial inequity (Nelson, Stahl, \& Wallace, 2015). Students from the lowest quartile family income have a dropout rate of $10 \%$ compared to $3.2 \%$ highest quartile (Center for Research on Education Outcomes, 2015; Dwyer, Hodson, \& McCloud, 2013).

Data from "Monitoring the Future" surveys provide strong evidence that women now far out-number men among recent college graduates in most industrialized countries (Vincent-Lancrin, 2008). Interestingly, women have not only overtaken men regarding college completion, but also have overtaken them in educational attainment. Girls have shown these gender disparities in academic performance in secondary schools (Grades 8 and 12 over the last three decades) (Fortin, Oreopoulos, \& Phipps, 2015). The study also explored issues related to gender over time that could account for the growing gender disparity in academic achievement. These include plans for the future, the family environment, and working while in school. Among seniors, boys' expectations about attending higher education were lower as compared to expectations of females (Fortin, Orelpoulos, \& Phipps, 2015).

\section{Differences in Level of Violence in Today's Schools Based on School Structure and Gender}

Victimization at school may be associated with student characteristics (including gender, race/ethnicity, grade level, and household income) or school characteristics (for example, whether a school is public or private) (Center for Constitutional Rights Foundation, 2017; IES/NCES, 2017). The relationships between these characteristics and student victimization are examined below:

Gender. In the school year 2008-2009, a larger percentage of male students than female students were the victim of any crime at school (4.6\% vs. 3.2\%). A higher percentage of males than females reported being the victim of theft ( $3.4 \%$ vs. $2.1 \%$ ), but there was no measurable difference between the percentages of male and female students who reported being the victim of violent crime (1.6\% and $1.1 \%$, respectively). A higher proportion of both male and female students reported theft victimization than a violent victimization- $3.4 \%$ males reported a theft victimization vs. $1.6 \%$ who reported a violent victimization, and $2.1 \%$ females reported a theft victimization vs. $1.1 \%$ who reported a violent victimization.

Race/Ethnicity. No measurable differences were found among the percentages of White, African-American, Hispanic students, and students of all other races who reported being the victims of any crime, theft, or violent crime at school in the academic year 2008-2009. Between both White and Hispanic students, a higher percentage of students were victims of theft than of violent crime (2.9\% vs. $1.2 \%$ for White students and $3.0 \%$ vs. $1.3 \%$ for Hispanic students).

Grade level. In the school year 2008-2009, a higher percentage of students in Grade 9 reported theft victimization (4.9\%) than did students in Grades 7 or 8 (2.1\% and 2.0\%, respectively). Also, higher percentages 
of students in Grades 9, 10, and 11 reported theft victimization (4.9\%, 3.5\%, and 3.3\%, respectively) than did students in Grades 6 or 12 (1.3\% and 1.5\%, respectively). No measurable differences were foundin a comparison of the percentages of students in Grades 6-11 who were victims of violent crime.

Household income. No measurable differences were found among family income levels and the percentages of students who reported being victims of any crime, theft, or violent crime at school in school year 2008-2009.

Public vs. private schools. The percentage of public school students who reported being victims of any offence (4.1\%) was higher than that of private school students (1.8\%) in the academic year 2008-2009.

\section{Looking More Closely on the Relationship of Environmental Impact and Violence}

Race and ethnicity, income levels, and other measurable elements have often been singled out by public health experts as risk facts that can contribute to ani-social behavior, from smoking and drinking to violent behavior and suicide. However, according to a survey in 2001 of U.S. adolescents conducted at the University of Minnesota and published in the American Journal of Public Health (Vol. 90, No. 12), these measurable factors only partially explain adolescent health risk behaviors. Investigators say that more important are school performance, the nature of friends' behaviors, and family relationships. In short, immediate environments including schools, communities, peer groups, and families can exert a powerful influence on young persons' attitudes and behaviors. In a closer look at environment related to violence, the study found that almost $50 \%$ of all teenagers, regardless of their settings—rural, suburban, or urban—believe that their schools are becoming more violent. Therefore, while it is critical that schools and communities recognize that school violence needs to be addressed, it is also essential that they respect the hopes and rights of the majority of students who are neither perpetrators nor victims of school violence and who want nothing more than to receive a good education in a safe environment.

School size. Researchers at the National Center for Education Statistics (IES/NCES, 2017) found that discipline problems are often related to school enrollment size. Large schools tend to yield more discipline problems than small schools. Thirty-four percent of schools with 1,000 or more students reported student disrespect for or assaults on teachers at least once per week, compared with $21 \%$ of those at schools with 500-999 students, $17 \%$ of those at schools with $300-499$ students, and $14 \%$ of those at schools with less than 300 students.

Middle school students are more than twice as likely as high school students to be affected by school violence. Seven percent of Grade 8 stays home at least once a month to avoid a bully. Twenty-two percent of urban 11- and 12- year-old know at least one person their age in a gang. The typical victim of an attack or robbery at school is a male in the Grade 7 who is assaulted by a boy's age. Studies suggest two reasons for the higher rates of middle school violence. Firstly, early adolescence is a difficult age. Young teenagers are often physically hyperactive and have not learned acceptable social behavior. Secondly, many middle school students have come into contact for the first time with young people from different backgrounds and outlying neighborhoods.

Community environment. As with schools and families, communities can neglect children. If the communities are not responsive to the needs of families and their children, this neglect can develop into school violence. After-school and summer programs are not always available. A child who starts acting violently will often do so during periods of unstructured and unsupervised time. Juvenile-justice statistics show that lacking 
after-school supervision, youth violence rises to above average rates between 3 and 7 p.m.. School violence has also been linked to the transformation of communities. Constantly, shifting school demographics often reflect larger upheavals as communities change size, economic well-being, and racial and ethnic mix.

\section{Conclusion}

We are faced with choices everyday and some are more imperative and impressive than others. These daily choices are sometimes made on past practice-what we learned that has worked and has not worked. Sometimes, a choice is based on an intuition and other times on simply not caring. When it comes to school choice, it is important to look at multiple variables — cost, quality of the teacher, the resources, and the building in which education takes place. It is also dependent on the consensus of the family and what is the best match for the student. This paper helped to bring the choice decision more into focus with variables that impact a child's learning over a long period of time. This is perhaps the most important aspect of choice, as it affects student achievement. It is not a decision that can take place unless those who make this choice bring into consideration background research, thought, and a true understanding of the reality of which school aligns with the learner.

\section{Focus on Research Question for the Future}

As the attention to supporting charter schools in the U.S. is now on the forefront of the new administration's agenda, it is important that researchers craft a design to look at this phenomenon. The following suggestions provided by the Center for Public Education (2017) help to set the compass. It is anticipated that others who are considering the issue of school choice will add to this set of opened-ended questions. These are also guides for meaningful discussions that need to be explored in public and social setting-issues that help uncover bias, help to gather relevant data, and form meaningful consensus in an open

forum. The bottom line is that the focus needs to be on two essential outcomes: student achievement and success.

1. What are the ingredients that contribute to charter school success, public school success? To private school success? To home-school success?

2. Do smaller class sizes, longer days, parent involvement, or freedom from collective bargaining and other regulations play a part?

3. Is there a difference between public charter schools and private charter schools?

4. What about the local school district role? What variables count most?

5. What is not an essential part of school success?

6. What effects do different governance models have on positive charter school outcomes? How do these effects compare to governance models that are inherent in public school settings?

7. What interaction exists between traditional and charter public schools?

8. Is there any evidence of shared ideas and information? Innovation?

9. Does the charter's authorizer affect the results?

10. What are charter schools' effects on local school districts regarding funding, governance, logistics, and accountability, or performance?

11. Where are you getting your information? Is it well-founded? 
There is no single clear-cut, definitive answer to the effectivequestion of charter schools. Careful study, persistence, patience, and data analysis might provide the answers to myriad questions.

\section{References}

Abdul-Alim, J. (2016, April). Charter high school grads persist in college, Earn higher salaries. In The 6th Annual International Colloquium on Black Males in Education (ICBME): Diverse Issues in Higher Education. Retrieved April 11, 2017, from http://www.diverseeducation.com/article/83082/

Bureau of Justice. (2017). Statistics on violence. Retrieved March 12, 2017, from https://www.bjs.gov/index.cfm?ty= tp\&tid=31

Center for Disease Control and Prevention. (2015). School violence: Data \& statistics. Retrieved March 11, 2017, from https://www.cdc.gov/violenceprevention/youthviolence/schoolviolence/data_stats.html

Center for Public Education. (2017). School choice: What the research says. Retrieved March 11, 2017, from http://www.center forpubliceducation.org/Main-Menu/Policies/School-Choice-What-the-Research-Says-At-a-Glance

Center for Research on Education Outcomes. (2015). Urban charter school study report on 41 regions. Stanford, C.A.: Stanford University. Retrieved March 17, 2017, from https://www.urbancharters.stanford.edu/download/Urban\%20Charter\%20School\% 20Study\%20Report\%20on\%2041\%20Regions.pdf

Center for Constitutional Rights Foundation. (2017). Causes of school violence. Retrieved March 12, 2017, from http://www.crfusa.org/school-violence/causes-of-school-violence.html

Dwyer, R. E., Hodson, R., \& McCloud, L. (2013). Gender, debt, and dropping out of college. Gender \& Society, 27(1), 30-55.

Ferrara, M. M., \& Holback, M. (2015). Whiteness and diversity: Blending tones through critical race theory. National Journal of Urban Education and Practice, 8(3), 366- 377.

Fortin, N. M., Oreopoulos, P., \& Phipps, S. (2015). Leaving boys behind: Gender disparities in high academic achievement. Journal of Human Resources, 50(3), 549-579.

Gloeckner, G. W., \& Jones, P. (2013). Reflections on a decade of changes in homeschooling and the homeschooled into higher education. Peabody Journal of Education, 88(3), 309-323.

Great Schools (2017). Private vs. public. Retrieved March 11, 2017, from http://www.greatschools.org/gk/articles/private-vspublic-schools/

Hanna, L. G. (2012). Homeschooling education: Longitudinal study of methods, materials, and curricula. Education and Urban Society, 44(5), 609-631.

Hess, F. (2002). Revolution at the margins: The impact of competition on urban school systems. Washington, D.C.: Brookings Institution.

Institute of Education Sciences (IES)/National Center for Education Statistics (NCES). (2017). Digest of education statistics. Retrieved March 14, 2017, from https://nces.ed.gov/programs/digest/d15/ch_2.asp

Isenberg, E.J. (2007). What have we learned about homeschooling? Peabody Journal of Education, 82, 387-409.

Kutzman, R. (2009). Understanding homeschooling: A better approach to regulation. Theory and Research in Education, 7 , 311-303.

Lubienski, C., Puckett, R., Brewer, T., \& Jameson, T. (2013). Does homeschooling “work?” Critique of the empirical claims and agenda of advocacy organizations. Peabody Journal of Education, 88(3), 378-392.

Males, M. A. (1998). Framing youth: Ten myths about the new generation. Monroe, M.E.: Common Courage.

Mazama, A., \& Lundy, G. (2013). African-American homeschooling and the question of curricularcultural relevance. The Journal of Negro Education, 82(2), 123-138.

Mead, J. F., \& Green, P. C. (2012). Using charter school legislation and policy to advance equal educational opportunity. Boulder, C.O.: National Education Policy Center.

National Alliance for Public Charter Schools. (2017). About the National Alliance. Retrieved March 11, 2017, from http://www.publiccharters.org/get-the-facts/about-us/

National Education Society on Violence. (2017). School violence: Data and statistics. Retrieved March 12, 2017, from https://www.google.com/search?q=National+Education+Society+-+Violence\&rlz=1C5CHFA_enUS705US705\&oq=national \&aqs=chrome.1.69i57j69i59l3j69i65j0.4625j0j1\&sourceid=chrome\&ie=UTF-8

National Student Clearinghouse. (2015). Student tracker for high schools aggregate report. Retrieved April 15, 2017, from http://www.studentclearinghouse.org/high_schools/studenttracker/ 
Nelson, J., Stahl, G., \& Wallace, D. (2015). Race, class, and gender in boys' education: Repositioning intersectionality theory. Culture, Society \& Masculinities, 7(2), 171-187.

Niche, B. (2017). Private schools vs. public schools. Retrieved April 17, 2017, from https://www.articles.niche.com/privateschool-vs-public-school-breakdown/

Pahlke, E., Hyde, J. S., \& Allison, C. M. (2014). The effects of single-sex compared with coeducational schooling on students' performance and attitudes: A meta-analysis. Psychological Bulletin, 140(4), 1042-1072.

Prep, U. (2016, April). Change the narrative. Retrieved March 19, 2017, from http://www.changethenarrative.today/home/about-10change/

Public School Review. (2016). Comparing private, public and charter schools. Retrieved May 12, 2017, from https://www.publicschoolreview.com/blog/comparing-private-public-and-charter-schools

Ray, B. D. (2011). 2.04 million home-school students in the United States in 2010. Salem, O.R.: National Home Education Research Institute. Retrieved September 13, 2017, from http://www.nheri.org.nr.idm.oclc.org/ HomeschoolPopulationReport 2010 pdf.

Singleton, G., \& Linton, C. (2006). Courageous conversations about race: A field guide for achieving equity in schools. Thousand Oaks, C.A.: Corwin.

Social Solutions. (2017). A divided mind: Charter schools vs. public schools. Retrieved April 21, 2017, from http://www. socialsolutions.com/blog/charter-schools-vs-public-schools

United States Department of Education. (2006). Indicators of school crime and safety. Retrieved March 21, 2017, from https://www.nces.ed.gov/programs/crimeindicators/

United States Department of Justice. (2015). National crime victimization survey. Retrieved March 22, 2017, from https://www.bjs.gov/index.cfm?ty=dcdetail\&iid=245

Vincent-Larcrin. S. (2008). Higher education to 2030. In Demography (Vol. 1). Paris, France: Centre for Educational Research and Innovation.

Wermund, B. (2017). Public charter schools are walking the fine political line. Retrieved March 10, 2017, from http://www. politico.com/tipsheets/morning-education/2017/06/09/public-charter-schools-walking-fine-political-line-220761 